\title{
Skeleton Coast National Park - geology to die for
}

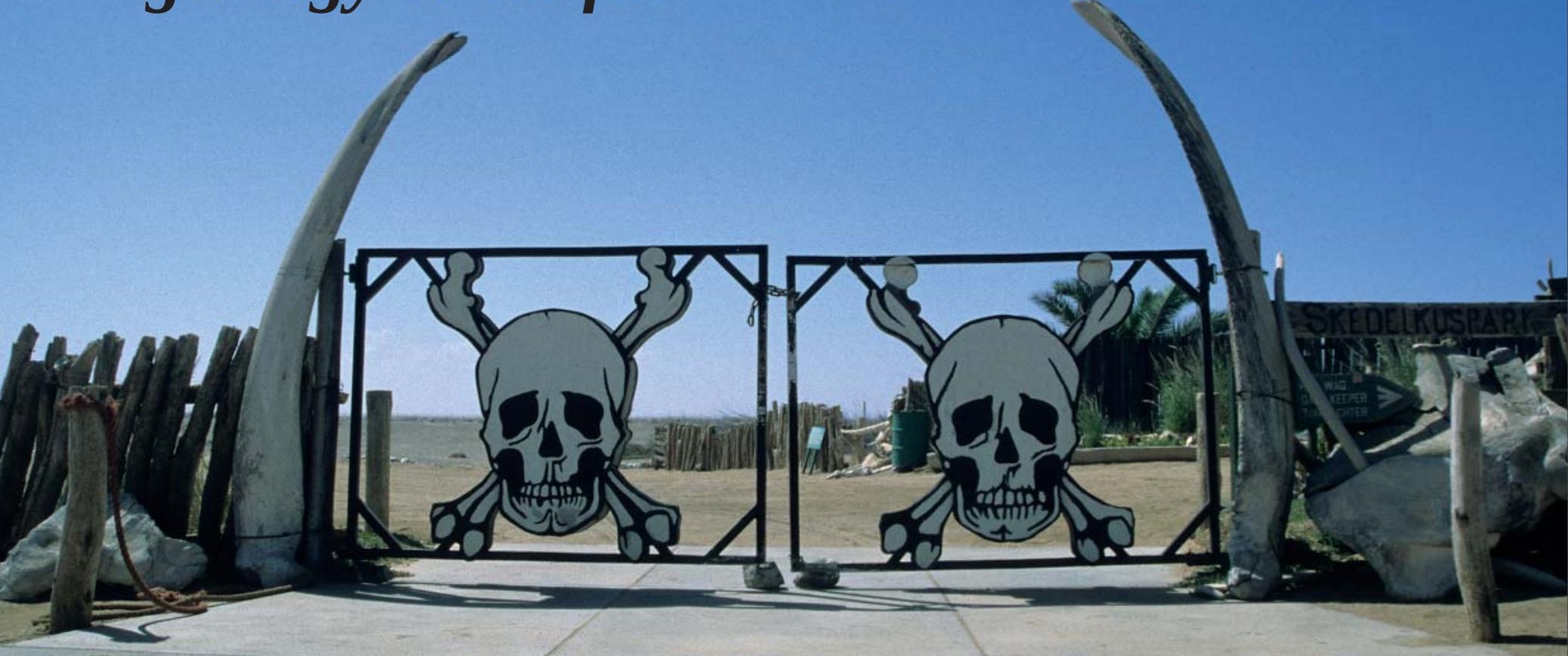

Ugab Gate. (Foto: Forfatteren)

Af geolog Johan Svendsen, Altinex Oil Denmark

Med maj-måneds fødsel af Shiloh Nouvel (Angelina Jolies og Brad Pitts datter) i Namibia, blev det lille vestafrikanske land - og ikke mindst dets skønhed - allemandseje. Tiden er derfor moden til at berette om to måneders feltarbejde i Skeleton Coast Nationalparken samt dannelsen af de fluvio-æoliske sedimenter, der kendetegner denne ørken.

Formålet med dette indlæg er dels at give et indblik $i$ et af de mest forskelligartede geologiske områder i verden dels også at give den eventyrlystne geologi-interesserede en appetitvækker til et utraditionelt feriemål.

I artiklen præsenteres forskningsresultater baseret på kombinationen af sedimentologi, geokemi og stratigrafi støttet af en række andre geologiske discipliner.

\section{Skeleton Coast Nationalpark}

Skeleton Coast Nationalparken langs den nordligste del af Namibias Atlanterhavskyst er et pænt stykke "off the beaten track". Men netop denne afsondrethed giver Skeleton Coast sin sjæl og charme. Indgangsporten til nationalparken præges af et par gigantiske dødningehoveder, der - ifølge vandrerhistorierne - vidner om skibsbrudne sømænd, der dør i de ubarmhjertige klitter. Men navnet henviser nok nærmere til de mange strandede hvaler på den meget fladbundede strand.

Nationalparken strækker sig fra Ugab Floden i syd til Kunene Floden i nord. Ind imellem disse floder krydser også Huab, Koichab og Uniab Floderne, der alle har oplandsområde i det højtliggende østlige $\mathrm{Na}-$ mibia og munder ud i Atlanterhavet. Adgang til parken sker gennem Ugab Gate, hvor alle besøgende skal indregistreres. Dette skyldes områdets store sårbarhed over for uhæmmet turisme. Det ekstreme klima, hvor der kan gå adskillige år uden nedbør, gør, at hjulspor og andre spor fra menneskelig aktivitet forbliver i landskabet i årtier.

\section{Regionalgeologi}

Namibias geologi består primært af gamle magmatiske og metamorfe bjergarter fra den stabile afrikanske kraton. I disse bjergarter findes diamanter og andre mineraler, der udgør en vigtig del af Namibias økonomi. I Jura startede åbningen af Sydatlanten med begyndende rifting og dannelse af lokale sub-bassiner, inden den egentlige oceanbundsdannelse gik i gang. Åbning af

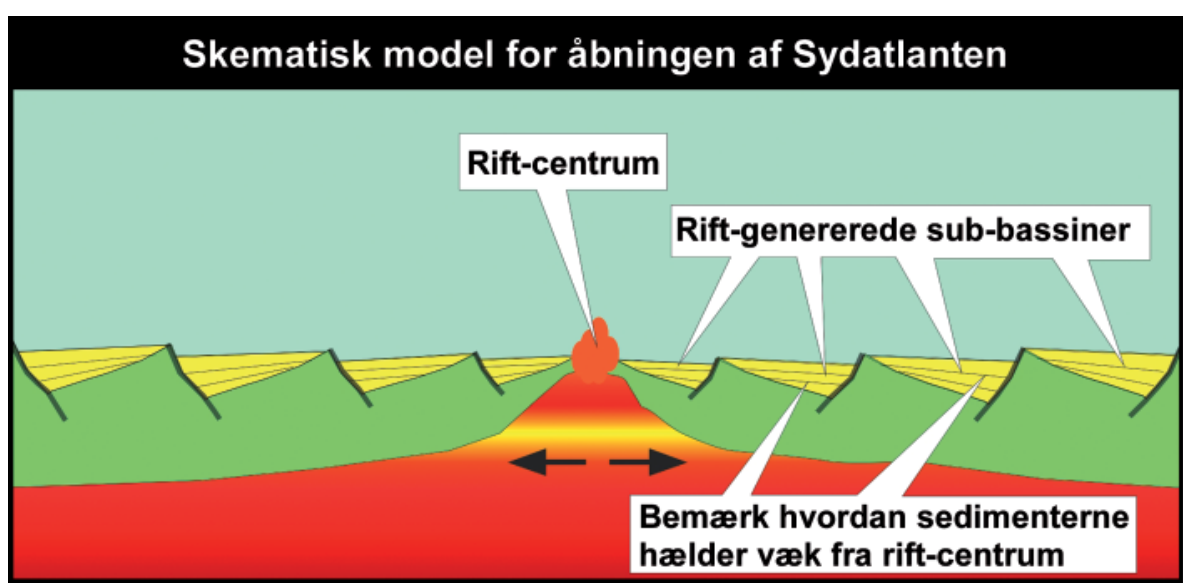

Simplificeret figur, der viser tiltede bassiner ved en begyndende rifting. (Grafik: Forfatteren) 

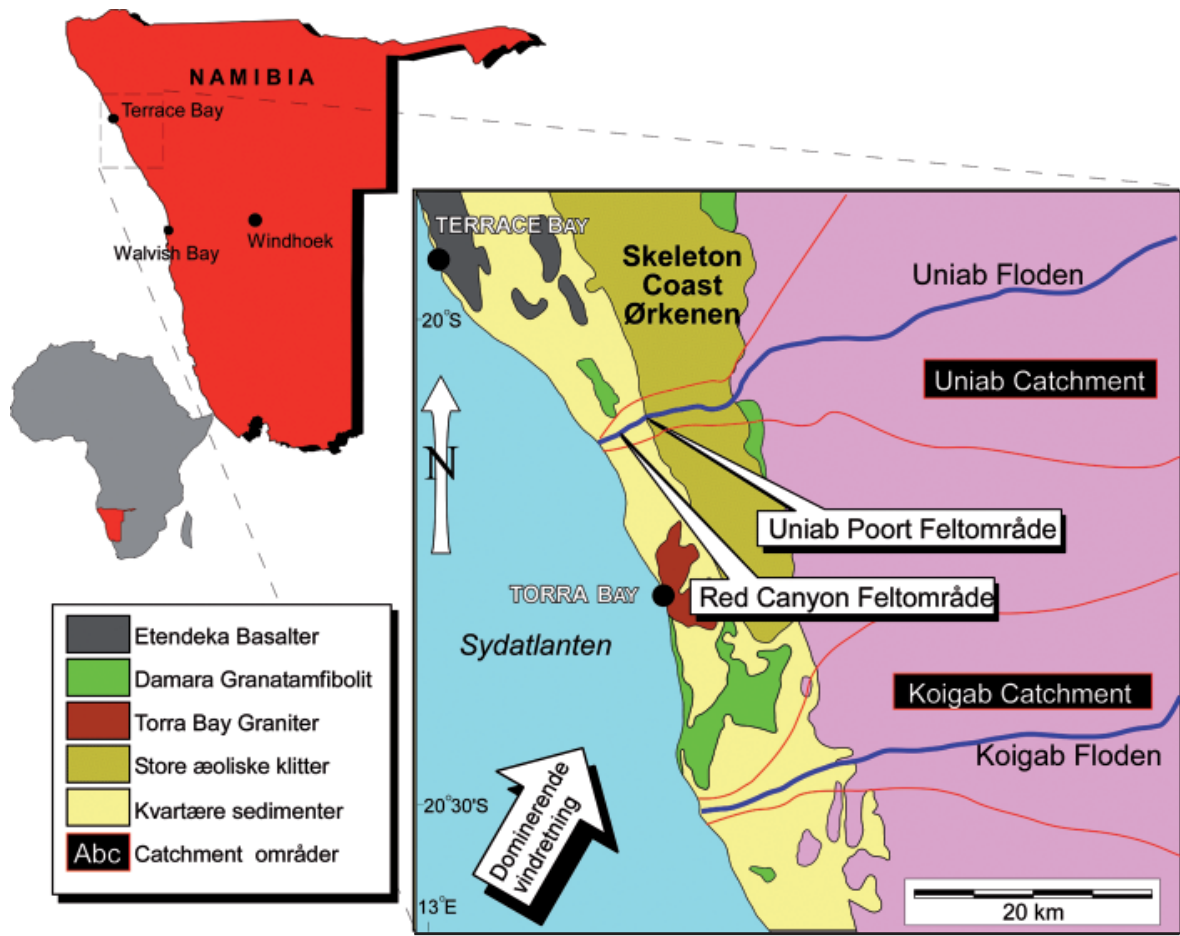

Kort der viser Namibias placering på det afrikanske kontinent. Endvidere detaljekort over geologien i Skeleton Coast Ørken-området. (Grafik: Forfatteren)

Sydatlanten var helt eller delvist kontrolleret af Tristan kappediapir (en kappediapir er et område, hvor relativt varmt og let kappemateriale suser op mod skorpen, med samme hastighed som en fingernegl gror. Geologisk set er dette en dramatisk hastighed, og kappediapirer har stor indflydelse på kontitnenternes samling og opsplitning). Tristan kappediapir befinder sig nu under den sydlige del af Afrika, og er med til at skabe den markante topografiske forskel mellem Namibias Atlanterhavskyst og det centrale højland. I forbindelse med åbningen af Sydatlanten blev der dannet en række mindre riftbassiner. Ved en sådan rifting vil sub-bassinerne hælde væk fra rift-aksen, således at sedimenterne hælder væk fra det egentlige rift-fokus, i dette tilfælde væk fra Atlanterhavet.

Geologien i Skeleton Coast Nationalparken er kendetegnet ved en stor variation, spændende fra prækambriske granatamfibolitter til recente fluviale deltaer, hvor der findes diamanter. De to altoverskyggende geologiske formationer er de jurassiske Etendeka Basalter og de kvartære klitdannelser i selve Skeleton Coast ørkenen. Udover disse spektakulære og verdenskendte formationer, er kun en lille del af geologien i området beskrevet. Det betyder for eksempel at en op til hundrede meter mægtig, rødlig, terrestrisk sekvens i området aldrig tidligere er beskrevet.

\section{Red Canyon Formation}

Denne rødlige terrestriske formation blev underkastet en nærmere undersøgelse. Formationen er blottet i Uniab Flodens munding i en afstand på 500-1.500 meter fra klaster viser, at de er mindre forvitrede, jo længere man bevæger sig op i formationen. Dette er tolket som et klassisk eksempel på "unroofing" (se figuren nederst næste side) af kildeområdet. Etendeka Basalterne blev i Jura/Kridt-tiden udsat for intens forvitring og blev efterfølgende eroderet af floder, således at bunden af den fluviale sekvens indeholder de basaltfragmenter, der oprindeligt "lå øverst", mens toppen af den fluviale sekvens indeholder klaster fra den mere "friske" basalt. Den øvre del af Red Canyon Formation er domineret af flodsengsaflejringer med enkelte fluviale lag, formodentlig crevasse splays og oversvømmelseslag. I de overvejende siltede halvkedelige sedimenter, findes der nogle interessante knoglelignende fragmenter. En nærmere undersøgelse af disse viser, at der er tale om dinosaurknogler. Desværre er knoglerne ikke så artsspecifikke, at det kan bestemmes, hvilken dinosaur der er tale om.

\section{Uniab Poort Profile}

Feltarbejdet i Skeleton Coast Nationalparken handlede primært om sedimentologi og geokemi af fluvio-æoliske sedimenter (betegnelsen fluvio-æolisk dækker over sedimenter, der er afsat i et miljø, der præges af en vekselvirkning mellem floder og klitter. Da sedimenterne fra hhv. floder og klitter er temmeligt forskellige, resulterer det ofte $\mathrm{i}$ meget spektakulær geologi). Et fremragende eksempel på denne sediment-type var blottet ved Uniab Poort, hvor Uniab Floden skærer sig igennem Skeleton Coast Ørkenbæltet. De blottede sedimenter fandtes i en godt 250 meter lang og op til 8 meter høj blotning af ukonsoliderede sedimenter. De sedimentære facies i profilet domineres af æoliske aflejringer, forskellige former for fluviale sedimenter samt lerede og sandede Basalter. En geokemisk analyse af disse system. Det flettede flodsystems aflejringer

Atlanterhavskysten og er kendetegnet ved terhavet. Formationens nedre del er blottet $i$ en kraftig nedskåret kløft (deraf formati( Canyon Formation). Den der ændrer karakter fra i bunden at være karakteriseret ved sedimenter aflejret i flettede flodsystemer, til i toppen at indeholde aflejringer fra et mere mæandrerende flod-

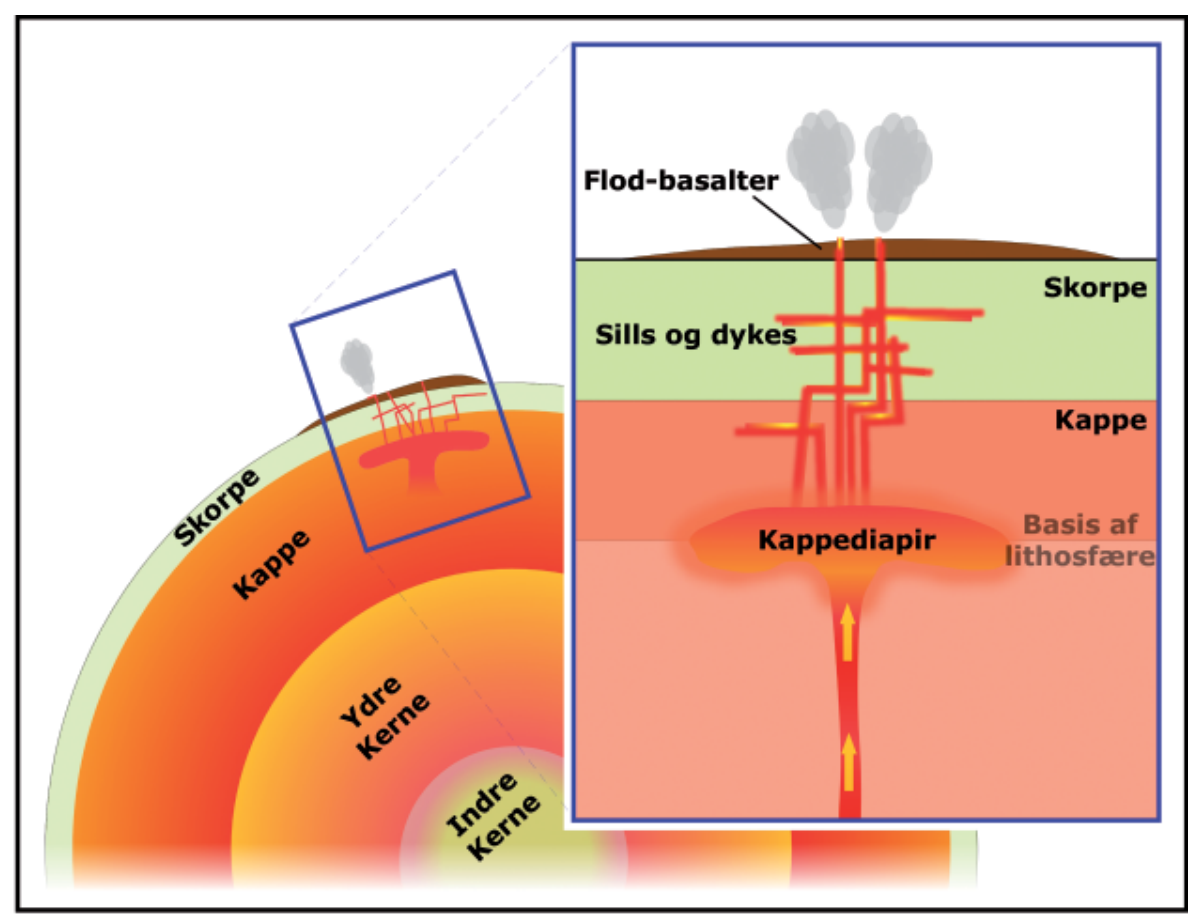

Skematisk figur af en kappediapir. (Grafik: Forfatteren) 

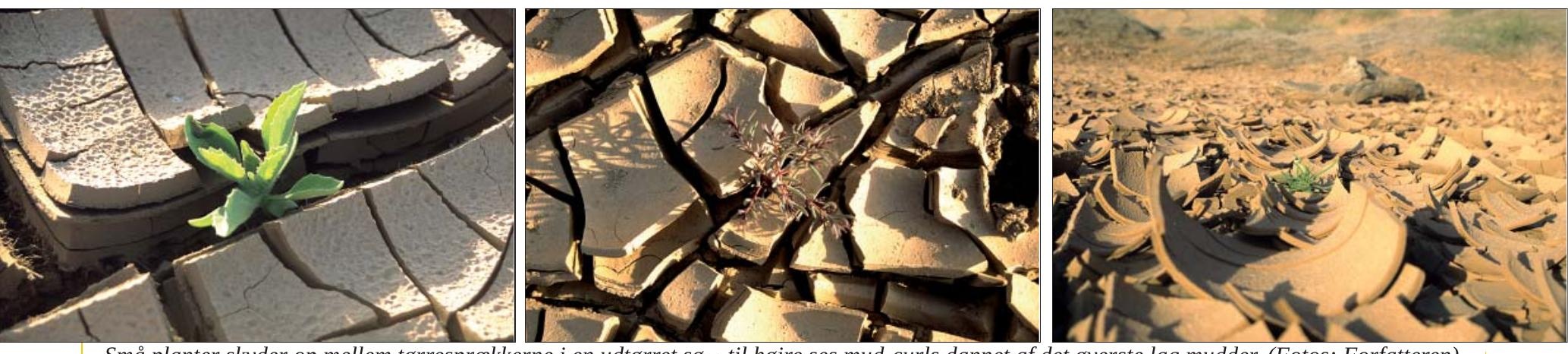

Små planter skyder op mellem tørresprckkerne i en udtørret sø - til højre ses mud-curls dannet af det øverste lag mudder. (Fotos: Forfatteren)

sø-sedimenter. Det bemærkelsesværdige ved disse sedimenter er den varierende grad af erosion fra de fluviale systemer. Visse af de fluviale systemer har absolut ingen erosiv kapacitet. De op til seks meter mægtige fluviale enheder draperer de æoliske forsets, og ofte kan de enkelte forsets følges i flere meter under den fluviale enhed. Dette virker meget besynderligt, idet flodsystemet formodentlig har været flere hundrede meter bredt og op til 10 meter dybt, og alligevel har det ikke kunnet erodere det løse klitsand (se foto og skitse på foregående side). I disse fluviale systemer ses hyppigt flydestrukturer, og i den nedre del ses invers gradering med klaster i den nedre del, men ikke i det basale lag.

Disse observationer viser, at det fluviale system var domineret af laminare strømningsforhold, formodentlig på grund af et ekstremt højt sedimentindhold. De efterfølgende fluviale systemer er kendetegnet ved kraftig erosion, og er tolket som aflejringer fra et fluvialt system domineret af turbulente strømningsforhold. Overgangen fra laminare til turbulente strømningsforhold skabes af den gradvise sedimentation fra det fluviale system. Disse forskellige former for fluviale systemer, dannet i direkte kontakt med æoliske sedimenter tænkes dannet ved følgende sekvens:
- Ved ekstreme mængder nedbør øst for klitfeltet dannes der pludseligt enorme floder - Disse floder opdæmmes af det op til hundrede meter høje klit-felt, hvorved der dannes kæmpestore søer

- Såfremt der falder tilstrækkelige mængder vand i oplandet, vil den opdæmmede sø nå en kritisk størrelse og vand vil begynde at strømme ind i klit-feltet

- Det strømmende vand eroderer klitterne, og floden får et meget højt sediment-indhold, der resulterer i dannelse af floder domineret af laminare forhold

- Efterhånden som sandet aflejres og/eller floden blandes med mere sediment-fattige floder, vil den resulterende flod domineres af turbulente forhold

Efter tidligere oversvømmelse er der rapporteret klaster af ukonsolideret æolisk sand på op til 4 meter på hver led. Mindre, men dog overbevisende klaster, blev set $\mathrm{i}$ selve Uniab-området (fotoet til højre nederst på næste side). Når klasterne, der består af relativt løst æolisk sand, ikke er disintegreret, viser dette, at strømmen ikke har været turbulent, men at klasten har "surfet" på overfladen af en laminar strømmende flod.

De laminare strømningsforhold, der tydeligvis har eksisteret i dele af den katastrofale gennembrydning af klitsystemet, kan kun dannes, når en vis mængde ler har været til stede i det fluviale system. Ved forvitrin- gen af basalterne i det fluviale kildeområde vil der naturligvis også dannes ler, fortrinsvis smectit, idet forvitring af vulkanske bjergarter (herunder basalter) primært danner smectit. Selvom den faktiske mængde af ler næppe har været mere end $5 \%$, danner det aflejrede ler, når det samles i små søer, nogle enestående geologiske former, så som $40 \mathrm{~cm}$ dybe tørresprækker og optil centimetertykke "mud curls". De finkornede sedimenter er aflejret i små søer mellem klitterne. I dette ugæstfri miljø finder selv de mindste frø pludselig en ufattelig livskraft, og få uger efter de store oversvømmelser spirer de nydeligste små blomster, samt den pudsige !nara-melon, frem.

\section{Sedimentær Geokemi}

Sedimentær geokemi kan overordnet inddeles i to metoder:

- enkeltkornsanalyse

- bulk-rock-analyser

De to metoder er nærmest selvforklarende, idet den førstnævnte analyse udelukkende baseres på kemien af et isoleret korn/mineral, mens den sidstnævnte er en analyse af den kemiske sammensætning af hele den indsamlede prøve.

Enkeltkornsanalyserne benyttes mest til at opnå information om det kildeområde, som kornet oprindeligt sad i, dets alder, petrologi osv. Bulk-rock-analysen vurderer
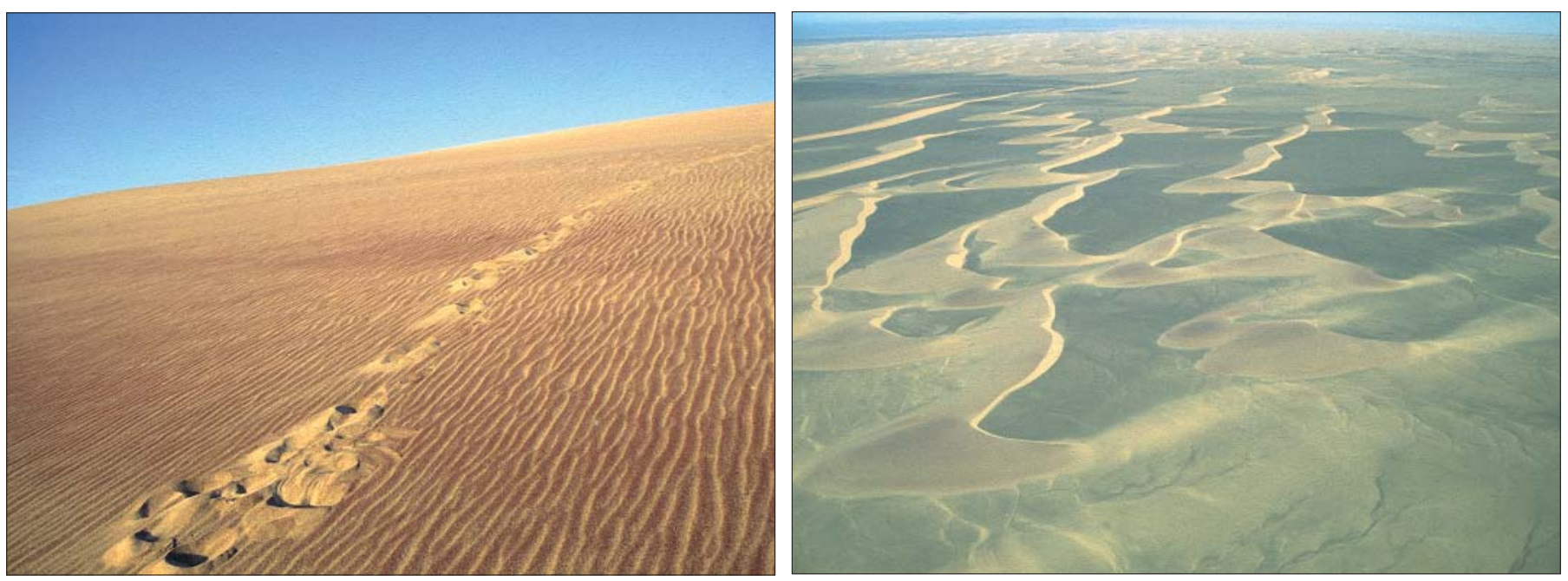

Til venstre ses en $100 \mathrm{~m}$ høj klit i den vestlige del af Skeleton Coast Ørkenen. Rødfarvningen skyldes granat. Antilopefodsporene uddgør skalaen. Til højre ses barkaner i den østlige margin af Skeleton Coast Ørkenen. Rødfarvningen på stødsiden skyldes granat. (Fotos: Forfatteren) 

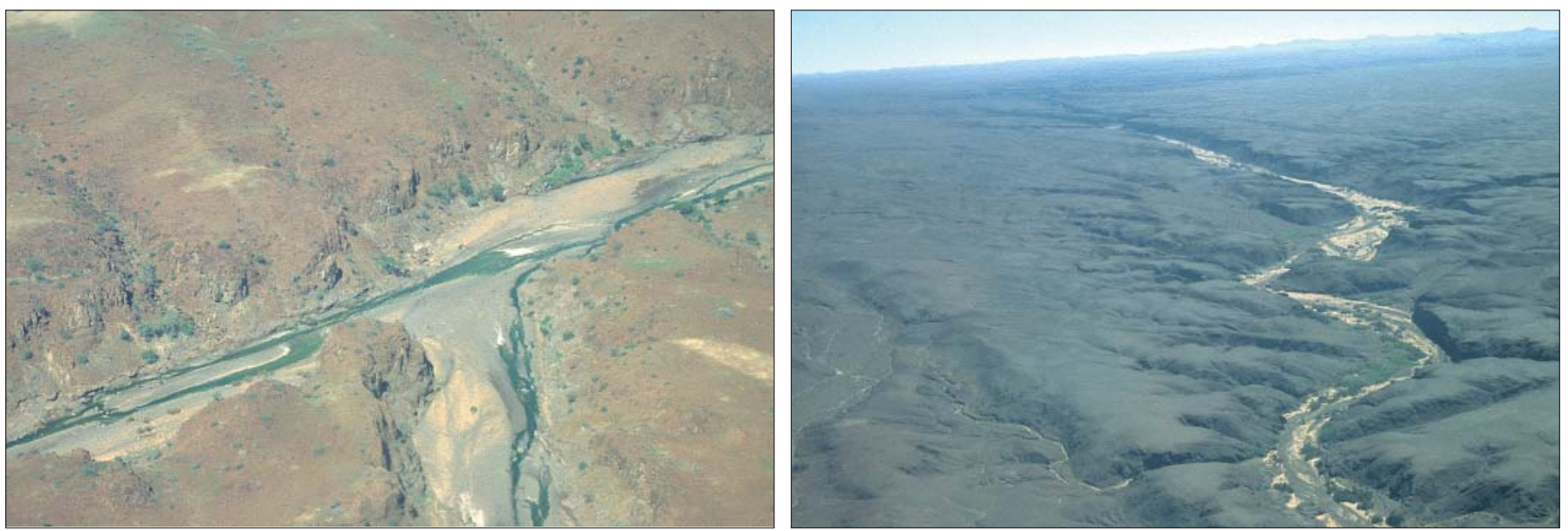

Billede til venstre: Floderne øst for Skeleton Coast skcrer sig ned i lavaerne dannet ved åbningen af Sydatlanten. Hér nedskcering i kvartslatitter. Til højre ses floderne øst for Skeleton Coast, der også skcerer sig ned i lavaerne - hér de kulsorte Etendekka-basalter (Fotos: Forfatteren)

mange flere korn og kan derfor bruges til at sige noget om, hvilke typer af mineraler der er i hele prøven, men dog uden mulighed for at give nogen særligt specifik analyse om de enkelte mineraler og deres oprindelse. De fluvio-æoliske sedimenter i Skeleton Coast Nationalparken adskiller sig fra langt de fleste andre geologiske sedimenter ved at kildeområde-problemet er ikke-eksistrende. Det fluviale kildeområde er indiskutabelt flodbasalterne øst for klifeltet. Dette område hælder hele vejen ned mod Atlantehavet, og de få floder skærer sig dybt ned i basalterne, som er rige på mafiske mineraler. Det æoliske kildeområde kunne være en stor blanding af geologiske formationer, men det faktum, at det blæser fra sydvest hver eneste dag, gør det lettere at vurdere, hvor sandet kommer fra. Den æoliske kilde er to-delt - den ene del er de kvartsrige strandzone- sedimenter, mens den anden del er de blottede granat-amfibolitter. Et hurtigt blik op af klitternes stødside afslører straks, at de granatrige amfibolitter spiller en ret stor rolle. Alle klitter i området har et rødt skær.

Det enestående faktum, at de fluviale og æoliske sedimenter har fuldstændigt forskellige kildeområde-sammensætninger, og at sedimenterne ikke har været udsat for nogen form for forvitring eller anden omdannelse, gør dem fremragende til at undersøge, om geokemien af sedimenterne kan afsløre deres sedimentologiske oprindelse. Geokemiske data giver en enorm datamængde, og en god og sober måde at angribe dette på er vha. statistisk. Da det vil føre for vidt at drøfte geokemi og geostatistik i dette indlæg, vil de endelige resultater blot blive vist. For den særligt interesserede læser henvises til artikler anført sidst i dette indlæg. Ved at

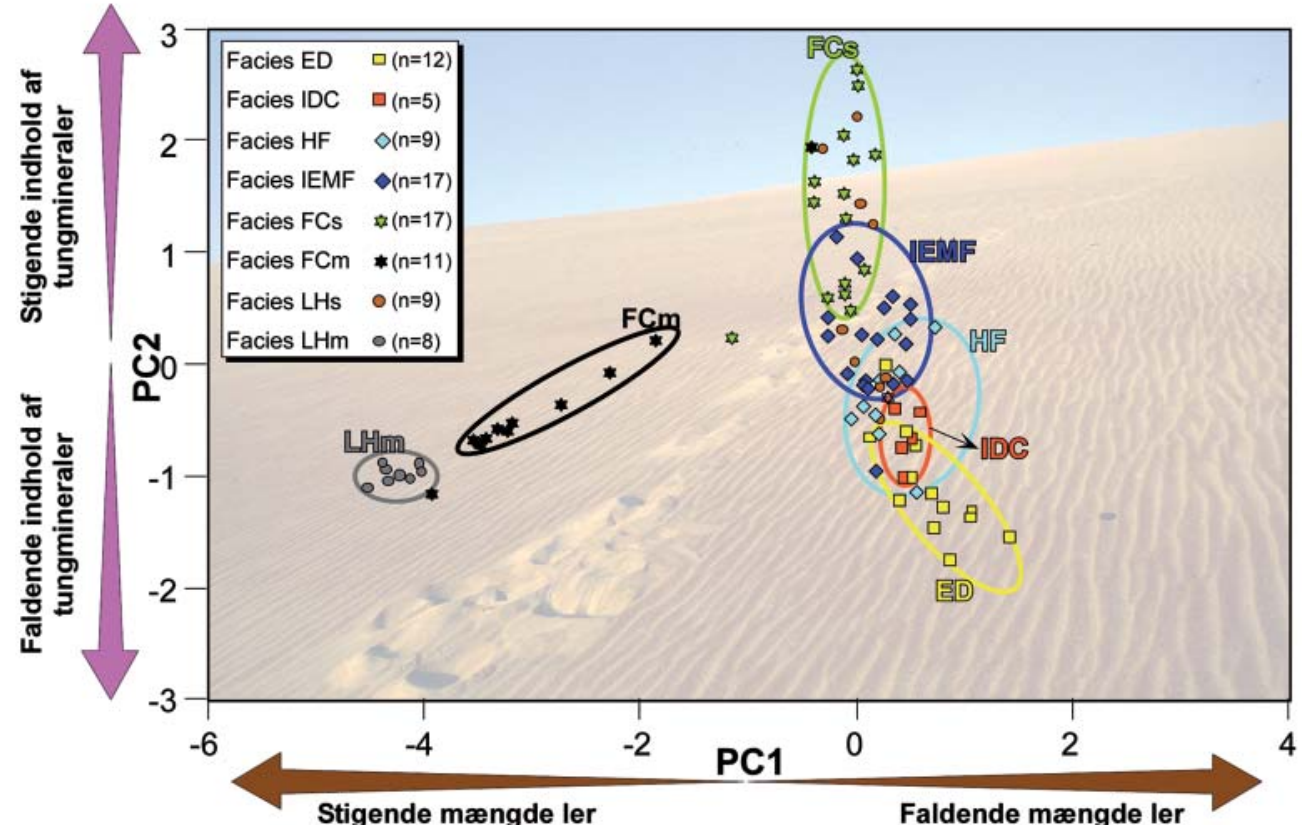

Ved hjcelp af geokemi lykkedes det at karakterisere de forskellige sedimentcere facies. Ved brug af geostatistik (Principal Component Analysis) lykkedes det at skille de enkelte facies så meget, at en kvantitativ sedimentologisk model kunne opstilles. (Grafik: Forfatteren) plotte de geokemiske data viser der sig en utrolig regelmæssighed. Som det ses, plotter de rene fluviale sedimenter (FCs) i den ene ende, mens de rene æoliske sedimenter (ED) plotter i den anden ende. Det ses endvidere, at de fluviale sedimenter, der var kendetegnet ved laminar flydning (IEMF), plotter imellem de to endepunkter, hvilket viser, at det fluviale sediment er dannet ved tilførsel af enorme mængder æolisk sand. De geokemiske data kan således give en kvantitativ idé om de sedimentologiske processer.

\section{Evaporitter}

Ingen artikler fra min pen uden en kommentar om salt. I Namibias kystregioner er der optimale forhold for dannelse af evaporitter med det salte Atlanterhav direkte op til en ørken. Disse forhold giver kyst-sabkhaer i stort set alle lavtliggende områder i kystområdet. Det udfældede salt cementerer ørkensandet til tykke skorper. Denne proces bruges også af det namibiske vejvæsen, der i stedet for at asfaltere vejene, overhælder dem med saltvand i middagssolen, hvorved der dannes en stabil overflade, som kan

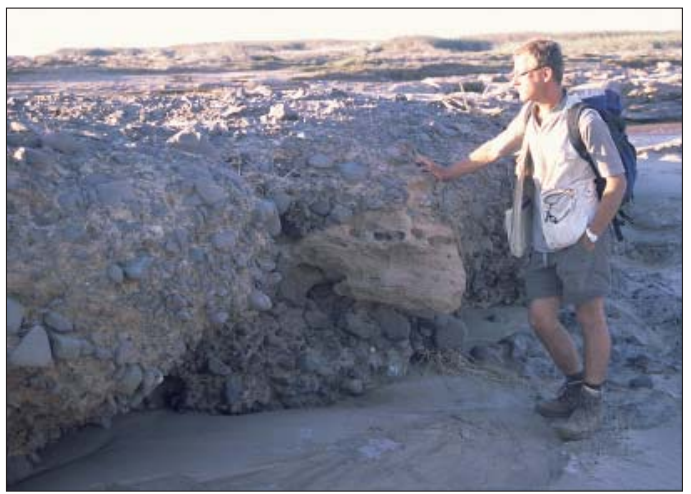

Den store lyse klast under den unge mands højre hånd er en ca $70 \mathrm{~cm}$ stor klast af løst, colisk sand, der har surfet oven på de sedimentmcettede flod. Efterfølgende er klasten sunket ned i sedimentet, og senere igen er hele pakken blevet cementeret (Foto: Forfatteren) 


\section{Benguela Havstrømmen}

Benguela Havstrømmen er dannet ved en sammenblanding af vand fra det sydlige Atlanterhav, Det Indiske Ocean og Antarktis. Havstrømmen løber fra Kap det Gode Håb op langs den afrikanske vestkyst og bøjer af mod nordvest ud for Benguela på den angolanske vestkyst. Det kolde, næringsrige vand bliver presset op til havoverfladen ud for den afrikanske kyst, hvilket medfører en eksplosion i antallet af plankton og sardiner, der bliver et utømmeligt spisekammer for tusinder af hajer, søløver og hvaler. Det iskolde vand har to implikationer for det namibiske klima. Luften over vandet er kold, og når den føres ind over land, bliver den varmet op, hvilket betyder, at mere vanddamp kan være indeholdt i luften, og det regner derfor ALDRIG langs den namibiske kyst. Den ekstreme temperaturgradient betyder desuden, at luften over kontinentet altid vil stige op og trække havluften ind fra sydvest. Derfor blæser det mere end 280 dage om året fra sydvest i Skeleton Coast Nationalparken. De oceanografiske forhold er derfor særdeles styrende for den geomorfologiske setting på land, en kyst-ørken med nordøst-migrerende klitter. Yderligere vil den konstante transport af vind fra havet samt opvarmningen af dette betyde, at der kommer nedbør, når denne luftmasse løftes op ved bjerge på kontinentet. Dette vil medføre floder, der vil løbe mod kysten og altså direkte imod den æolisketransportret-

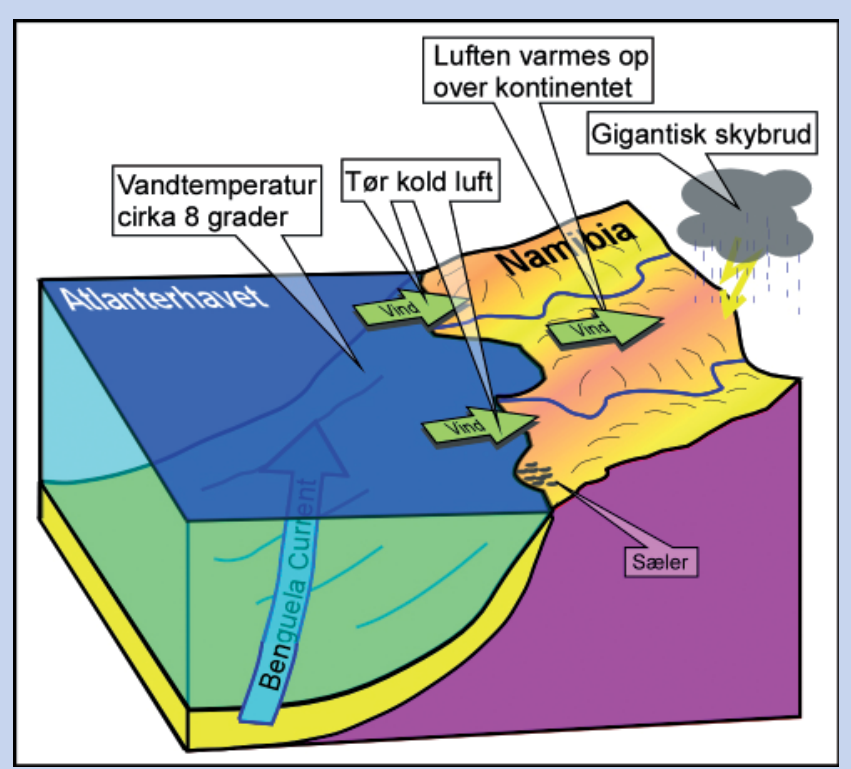

ning. Det er derfor sandsynligt, at den geologiske setting skabt af Benguela Havstrømmen ikke er unik, og det er tænkeligt at geologiske teorier fra Skeleton Coast Nationalparken kan overføres til såvel nutidige som tidligere ørkener. strandene, til fods - HUSK VAND!! - eller til flys. Fly-leje er relativt billig og giver en enestående mulighed for at forstå den store sammenhæng mellem de sedimentologiske processer. Dog skal man lige huske, at det lyse sand og de mørke basalter har en meget forskellig varmeabsorption og dermed varmeafgivelse, så det at flyve ind over Skeleton Coast Desert er vildere end selv den mest dristige rutschebane - husk en lille diskret papirspose.

I de største byer (alle tre) er overnatning ikke et problem, og der findes alt fra telt- områder til fine hoteller. Her findes der også velekviperede supermarkeder og specialforretninger, og der er ikke den tyske pølse eller hollandske ost man ikke kan få. Anderledes ser det ud i den $16.400 \mathrm{~km}^{2}$ store Skeleton Coast National Park. Her findes der fem små ansamlinger af huse, og i den ene af dem, Terrace Bay, findes der ligefrem en forretning, hvor man kan købe lidt cola, chips og småkager. Er ønsket mere luksuøse varer som ost, ris, chutney og tun, så må man køre de mere end $400 \mathrm{~km}$ til Swakopmund og tilbage igen - en tur på $800 \mathrm{~km}$ på grusvej, der, med lidt erfaring i off-roading, kan klares på cirka 8 timer.

I Swakopmund findes også den telefonboks, der tillader opkald til lande uden for det afrikanske kontinent. I Terrace Bay findes endvidere otte små hytter, som kan lejes for en, efter kvalitet og andre forhold, helt horribel pris. Det skyldes ganske enkelt, at dette er et af de bedste steder på hele den afrikanske kyst for kyst-fiskeri, og de rige sydafrikanere betaler hvad som helst for disse hytter. Under feltarbejdet i Skeleton Coast National Park fandt de fleste overnat-

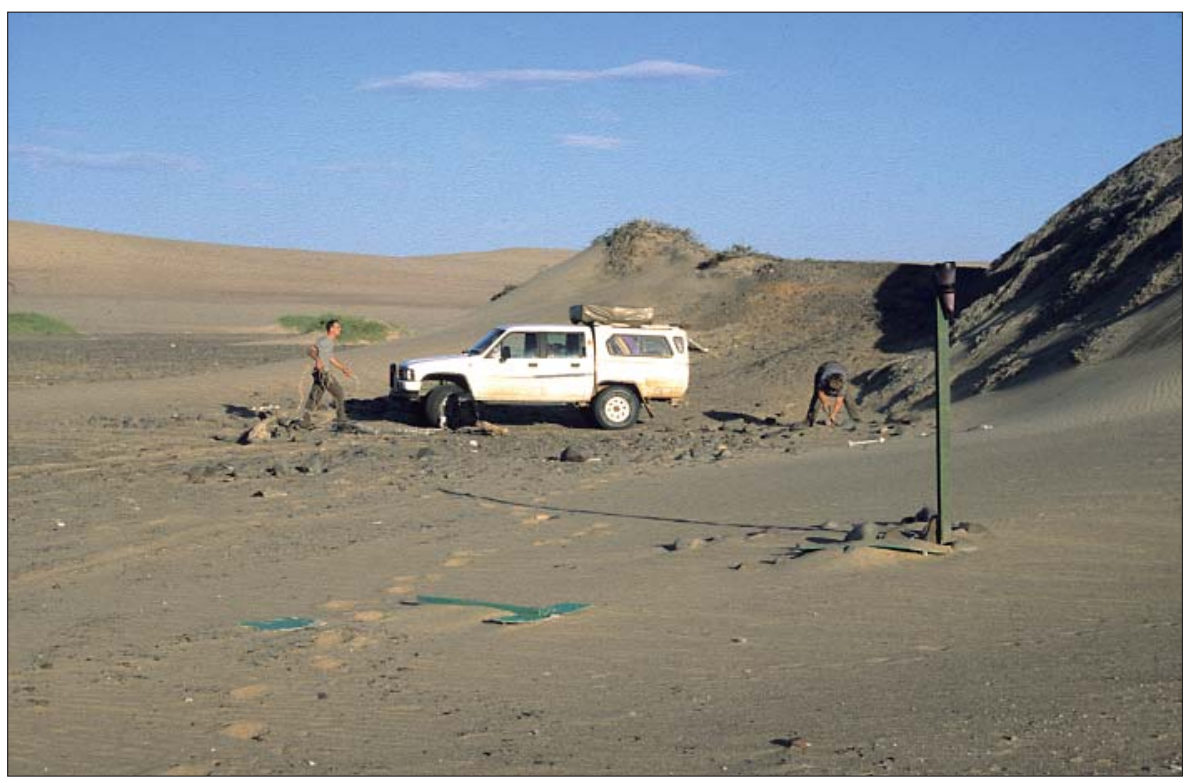

\section{Namibia}

- Størrelse: 825.418 km² $^{2}$ altså cirka 20 gange så stort som Danmark

- Hovedstad: Windhoek

- Befolkning: 1.800 .000

- Sprog: Engelsk og Afrikaans (officiel-

le) og Herero (oprindeligt) og tysk

- Vildtreservater: Etosha - $20.000 \mathrm{~km}^{2}$.

Blev oprettet i 1909

- Gennemsnitsalder: 43 år !!

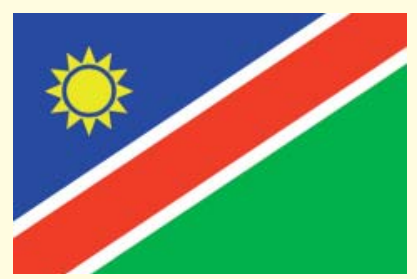




\section{Skeleton Coast National Park Research Project}

Forskningsprojektet i Skeleton Coast Nationalparken foregår under tysk ledelse med blandt andet Harald Stollhofen i spidsen. Men projektet er ikke bare et lille lokalt fænomen, idet mange universiteter bliver inviteret med til forskellige projekter. Lars Clemmensen (Geologisk institut, Københavns Universitet) var en af disse, og det var ham, der skaffede kontakten mellem forfatteren og $\mathrm{Ha}-$ rald Stollhofen.

ninger sted i et telt, på en luftmadras eller på bagsædet af en bil midt i den iskolde ørken.

Et par gange om ugen overnattede vi i Terrace Bay, på det lokale politikontors parkeringsplads, hvilket betød, at man kunne få et tiltrængt bad i byens eneste fællesbad.

\section{Afrunding}

Et besøg i Skeleton Coast Nationalparken er uden tvivl en oplevelse for livet - den afsondrethed, som man er nødt til at affinde sig med, skaber en ro, men også en forståelse for hvordan livet leves $i$ andre dele af verden. Efter at have set en del fluvio-æoliske sedimenter i blotninger og borekerner, var det en fantastisk oplevelse at få lov til at gå rundt i disse klitsystemer, flyve op ad de udtørrede floder og til at campere midt mel-

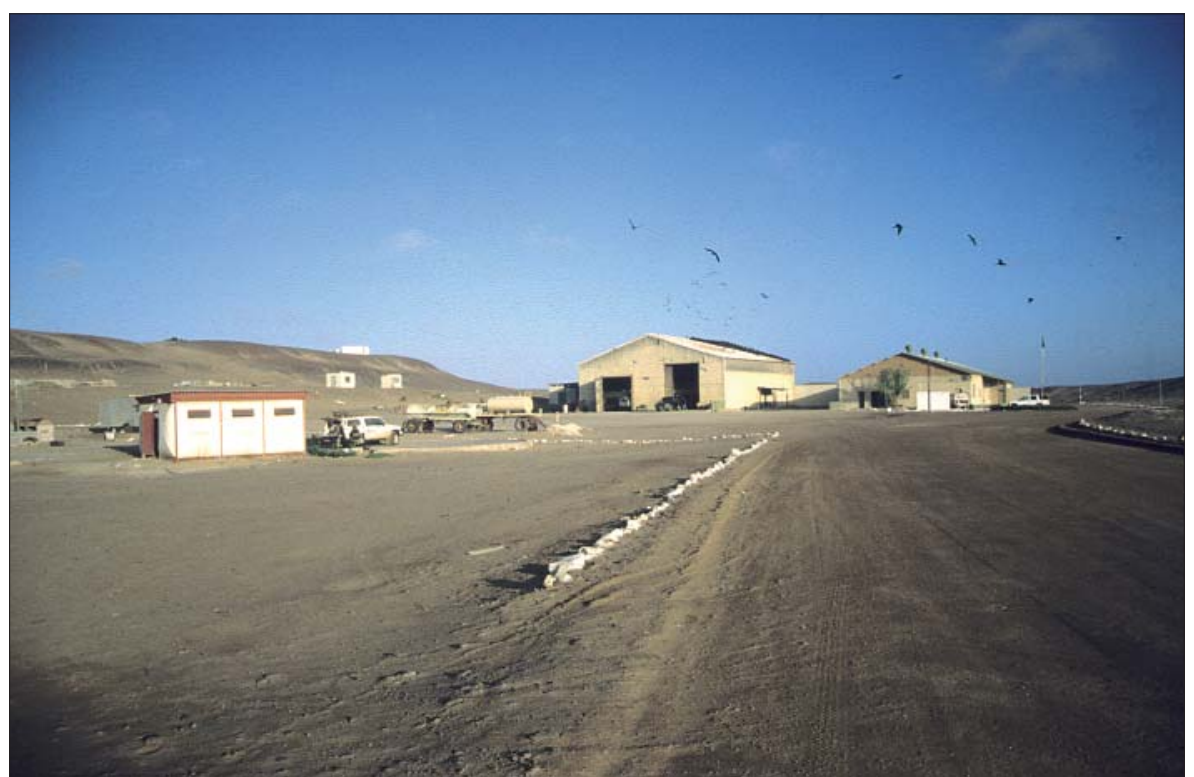

Mere luksuøse overnatningsforhold i Terrace Bay. Felt-toyota-cruiseren ses ved siden af det kommunale fcellesbad til venstre. Til højre ses den officielle myndighedsbygning. (Foto. Forfatteren)

lem vandrende barkaner.

Som geolog må man bare erkende at "The presence is the key to the past".

Yderligere litteratur:

Svendsen, J.B., Stollhofen, H., Krapf, C.B.E. and Stanistreet, I.G., 2003. Mass and hyperconcentrated flow deposits record dune damming and catastrophic breakthrough of ephemeral rivers, Skeleton Coast Erg, $\mathrm{Na}$ mibia. Sedimentary Geology, 160, 7-31.

Svendsen, J.B., Friis, H. Stollhofen, H. \&
Hartley, N.R., 2006. Facies discrimination in a mixed fluvio-aeolian setting using elemental whole rock geochemistry. Journal of Sedimentary Research - In press

\section{Namibias historie, økonomi og kultur}

Namibias ugæstfri kystlinie gjorde, at landet ikke var af interesse for de europæiske slavehandlere. I $1884 \mathrm{blev}$ landet tysk koloni og fik navnet Tysk Syvestafrika og var en af de tyske kolonier på det afrikanske kontinent. Landet har stadig en stor tysksproget minoritet. Sydafrika besatte Tysk Sydvestafrika under 1. Verdenskrig. Efter 2. Verdenskrig annekteredes territoriet af Sydafrika. I 1966 begyndte en selvstændighedskrig, men Sydafrika anerkendte ikke selvstændigheden før 1988, da FN havde frembragt en fredsplan for hele regionen. Formelt blev Namibia selvstændigt den 21. marts 1990, hvorefter man har afholdt demokratiske valg.

Namibias økonomi er præget af landets geologi, idet økonomien baserer sig på udvinding af mineraler til eksport. Minedriften står for $20 \%$ af BNP. Namibia er verdens femtestørste producent af uran. Namibia er også førende i verden inden for diamantudvinding - hvilket naturligvis skyldes det nærliggende Kimberly-område. Desuden udvindes store mængder bly, zink, sølv og tungsten. Den namibiske Atlanterhavssokkel har fået stigende interesse i jagten på olie og gas.

Majoriteten af befolkningen er sort. Ovambo-stammen er den største og udgør ca. halvdelen af befolkningen. Der er større grupper af San- og Nama-folk, som udseendemæssigt er svært forskellige fra det, som vanligvis opfattes som "sort". Den hvide befolkning i landet (ca. $6 \%$ ) er hovedsagelig af tysk oprindelse. Mens administrationssproget er engelsk, snakker størstedelen af befolkningen enten afrikaans eller tysk. En række indfødte sprog er også i brug. Kristendommen er den største religion, de fleste er protestanter. 